\title{
PARADA CARDIORRESPIRATÓRIA NA UNIDADE DE TERAPIA INTENSIVA: CONSIDERAÇÕES TEÓRICAS SOBRE OS FATORES RELACIONADOS ÀS OCORRÊNCIAS IATROGÊNICAS
}

\author{
CARDIOPULMONARY RESUSCITATION IN THE INTENSIVE CARE UNIT: \\ THEORETICAL CONSIDERATIONS ON FACTORS RELATED TO \\ IATROGENIC OCCURRENCES
}

\section{PARO CARDIORRESPIRATÓRIA EN LA UNIDAD DE CUIDADO INTENSIVO: CONSIDERACIONES TEÓRICAS SOBRE LOS FACTORES RELACIONADOS A LAS OCURRENCIAS IATROGÉNICAS}

Sandra Cristine da Silva* Kátia Grillo Padilha**

Silva SC, Padilha KG. Parada cardiorrespiratória na unidade de terapia intensiva: considerações teóricas sobre os fatores relacionados às ocorrências iatrogênicas. Rev Esc Enferm USP 2001; 35(4): 360-5.

\begin{abstract}
RESUMO
O atendimento na Parada Cardiorrespiratória (PCR) exige rapidez, eficiência, conhecimento científico e habilidade técnica. Ainda, faz-se necessário uma infra-estrutura adequada e a realização de um trabalho harmônico e sincronizado, pois a atuação em equipe é necessária para se atingir a recuperação do paciente. Os fatores iatrogênicos relacionados ao atendimento a PCR, na Unidade de Terapia Intensiva, podem ser resultantes de inexperiência profissional, insuficiência de pessoal e problemas de material e equipamentos. Dai a importância de preparar a equipe para ministrar assistência adequada, pois a reanimação deve restaurar o processo de vida e não prolongar o processo de morte.
\end{abstract}

PALAVRAS-CHAVE: Unidades de Terapia Intensiva. Parada cardiorrespiratória.

\begin{abstract}
The attendance of Cardiopulmonary Resuscitation (CPR) demands rapidity, efficiency, scientific knowledge and technical ability. Still, an adequate infra structure is vital as well as the accomplishment of an harmonic and synchronized work and team performance, in order to promote the patient's backup. latrogenic factors related to attendance of CPR in the Intensive Care Unit may be due to professional inexperience, insufficient staff and problems with material or equipments. Thus, the team must be prepared to assist the patient efficiently, as resuscitation should restore the life process and not prolong the death process.
\end{abstract}

KEYWORDS: Intensive Care Unit. Cardiopulmonary resuscitation.

\section{RESUMEN}

El atendimiento en el Paro Cardiorrespiratório exige rapidez, eficiencia, conocimiento científico y habilidad técnica. Todavia, se hace necesário una infra estructura adecuada y la realizacion de un trabajo harmônico y sincronizado, pues la actuacion en equipo es necesária para alcanzar la recuperacion del paciente. Los factores iatrogénicos relacionados al atendimiento del Paro, en la Unidad de Cuidado Intensivo, pueden ser resultantes de inexperiencia profesional, insuficiencia de personal y problemas de material o equipamientos. De ahi la importância del equipo para realizar asistencia adecuada, pues la reanimacion deve restaurar el proceso de vida y no prolongar el proceso de muerte.

PALABRAS-CLAVE: Unidades de Cuidado Intensivo. Paro cardiorrespiratória.

Enfermeira. Mestre em Enfermagem e Doutoranda pela EEUSP. Prof.

Dra do Depto de Enfermagem Médico Cirúrgica da EEUSP. 


\section{INTRODUÇÃO}

A Parada Cardiorrespiratória (PCR) é considerada como intercorrência de alto grau de complexidade, principalmente quando presente em pacientes que se encontram em estado crítico, como os internados na Unidade de Terapia Intensiva (UTI). Assim, o atendimento nesta circunstância exige da equipe multiprofissional rapidez, eficiência, conhecimento científico e habilidade técnica no desempenho da ação. Requer, também, para o sucesso do atendimento uma infra-estrutura adequada, que proporcione atendimento com o máximo de eficiência e um mínimo de riscos para o paciente e equipe. Além disso, é importante um trabalho harmônico e sincronizado entre os profissionais, pois a atuação em equipe é necessária para se atingir o maior objetivo da assistência, ou seja, a recuperação do paciente. Quando estes requisitos não são preenchidos, os riscos tornam-se evidentes, as ocorrências iatrogênicas frequentes e a segurança do paciente fica seriamente comprometida.

A PCR, em si, não representa um indicador de má qualidade da assistência, mas demonstra, sobretudo, o nível de gravidade em que o paciente se encontra. Uma vez presente, a chance de sobrevivência depende, em grande parte, da aplicação imediata, competente e segura das manobras de reanimação que precisam ser instituídas prontamente com o objetivo de evitar lesão cerebral irreversivel. Neste caso, o fator tempo constitui uma variável fundamental na recuperação do paciente ${ }^{(1-7)}$.

As manobras de reanimação isoladamente não alteram a sobrevida dos pacientes. No entanto, a prática precoce de manobras básicas seguidas da implantação também precoce e eficiente do suporte avançado, aumentam as chances de recuperação imediata e de sobrevida(6). Esta Associação, ainda, refere que a reanimação cardiopulmonar (RCP) tem como meta, além da preservação da vida, o alívio do sofrimento, a restauração da saúde e a limitação das incapacidades. Sendo assim, quando o início das manobras de reanimação for realizado tardiamente é possivel restabelecer as funções vitais por algum tempo, mas a lesão cerebral grave e irreversivel que se instala em decorrência da demora do atendimento, estará determinando a futura qualidade de vida do indivíduo.

Estudos indicam que aproximadamente 30\% das tentativas de RCP são bem sucedidas. Porém, dos pacientes que sobrevivem ao procedimento inicial, apenas $10 \%$ recuperam-se sem sequelas neurológicas ou com graus leves e moderados de incapacidade funcional. Quanto à mortalidade, $90 \%$ dos pacientes morrem no primeiro ano após o evento, dos quais 30\% direta ou indiretamente de causas neurológicas ${ }^{(8)}$.
A PCR é uma intercorrência comum a todas especialidades médicas. Por isso ela deve ser atendida em qualquer área hospitalar, que, por sua vez, necessita estar equipada e preparada para tal atendimento. A UTI é considerada como o melhor local por oferecer condições de tratamento ao paciente em estado crítico e frequentemente sujeito à PCR, e porque concentra uma infra-estrutura própria, com provisão de materiais e equipamentos necessários, bem como a presença de pessoal capacitado para o desenvolvimento da assistência especializada.

A internação de paciente na UTI demanda estabelecimento de tratamento intensivo para sua pronta recuperação. O alcance desse objetivo só será atingido na vigência de um atendimento adequado, sem falhas no decorrer da assistência ao paciente, o que também se aplica ao atendimento do indivíduo em PCR.

A assistência hospitalar deve estar voltada a um máximo de qualidade na assistência prestada, o que dentro do hospital e também na UTI implica na segurança do paciente. Tal segurança pressupõe, em outras palavras, um mínimo de falhas no decorrer do atendimento ao paciente e prevenção de todo e qualquer desvio que possa ocorrer durante o processo de internação. Implica, portanto na prevenção de ocorrências iatrogênicas que podem comprometer a recuperação do paciente, o que se aplica também para o atendimento de PCR na UTI(9-10)

Ocorrência iatrogênica é um "evento indesejável, de natureza danosa ou prejudicial ao paciente, consequente ou não de falha do profissional e que compromete ou tem o potencial de comprometer a segurança do paciente"(11). Lynch(12) refere que as ocorrências iatrogênicas, ocorrências adversas ou fatores iatrogênicos são termos utilizados como sinônimos, sendo também definidos como eventos potencialmente prejudiciais relacionados às intervenções daqueles que prestam cuidados aos pacientes. Beckmann, Baldwin, Hart, Runcimans ${ }^{(13)}$, abordando o termo incidente crítico, conceitua-o como um evento não intencional que reduz ou pode reduzir a segurança do paciente, traduzindo, dessa forma, conceito comum, aceito por unanimidade pelos estudiosos do assunto, independente de terminologia adotada.

Assim, o pleno êxito da assistência na UTI dependerá da presença de recursos humanos, financeiros, de materiais e equipamentos, bem como da determinação de papéis de cada profissional envolvido no processo. Ressalta-se ainda a importância técnico científica dos profissionais e a necessidade de protocolos de atendimento, visando a padronização das ações a serem seguidas, como forma de facilitar a abordagem terapêutica. Estas características no seu conjunto é que possibilitarão um atendimento eficaz em qualquer situação, destacando-se entre elas o atendimento a PCR. 
Apesar dessas considerações, nota-se que no cotidiano das atividades práticas nas UTIs nem sempre o atendimento à PCR ocorre de forma isenta de falhas, apontando, pois para a existência de fatores que devem ser conhecidos para a sua prevenção

\section{FATORES RELACIONADOS ÀS OCORRÊN- CIAS IATROGÊNICAS NO ATENDIMENTO À PCR}

Referente a presença de fatores relacionados as ocorrências iatrogênicas de uma forma geral, autores como Short(14); Hart(15); Beckmann, Baldwin, Hart, Runcimans(13); Buckley(16); Padilha ${ }^{(17,18)}$ apontam como os mais comuns os relacionados à inexperiência profissional, falta de atenção e desconhecimento técnico-científico dos integrantes da equipe, quantidade insuficiente de profissionais e problemas inerentes aos materiais e equipamentos utilizados na assistência ao paciente crítico, deixando evidente a existência de um amplo leque de fatores, das mais diferentes naturezas, envolvidos na gênese das ocorrências. Porém, um aspecto que tem merecido destaque por parte de estudiosos é o que se relaciona à capacitação dos profissionais que atende aos individuos na UTI.

Wright, Mackenzie, Buchan, Cairns, Price(19) em investigação sobre ocorrências iatrogênicas relacionados à assistência aos pacientes de UTI, demonstrou que, enquanto problemas relacionados aos materiais e equipamentos ocorreram em 20\% das situações, os $80 \%$ restantes foram decorrentes de problemas relacionados aos recursos humanos, apontando assim para a necessidade de investimento na educação em serviço por meio de treinamento e reciclagem periódica dos profissionais. Outro fator apontado por estes autores como prioritário para o aparecimento de ocorrências iatrogênicas em UTI, tem sido relacionado aos aspectos da alta tecnologia que, se por um lado pode trazer inúmeros beneficios aos pacientes, por outro pode desencadear sérios danos, quando o binômio paciente-máquina não é objeto de cuidadosa vigilância. Deve-se considerar que a tecnologia utilizada na UTI nunca deve suprimir o elemento humano, o qual terá sob sua responsabilidade a vigilância continua sobre paciente e equipamento a fim de atuar prontamente sobre possiveis intercorrências.

Corroboram essas afirmações, dizeres de Whitaker(20) quando afirma que a ausência de definição de tarefas, entre os elementos que compõem a equipe de atendimento, aliadas às faltas de coordenação das atividades, de treinamento especifico e às falhas no suprimento de material e equipamentos apropriados podem ser "consideradas como deficiências determinantes do atendimento moroso, tumultuado e estressante, frequentemente observado em nosso meio. Safar(1); Lopes(4); Gray, Capone, Most(21); Lane) também citam a falta de organização e treinamento adequados como responsáveis pelo atendimento precário e caótico em situações de PCR.

Em estudo sobre ocorrências iatrogênicas durante o atendimento à PCR na UTI, Silva(22) encontrou nos relatos da equipe de enfermagem, 176 fatores iatrogênicos relacionados ao atendimento desta intercorrência. Destes $58,6 \%$ envolviam falha na realização de procedimento técnico, enquanto que $31,2 \%$ eram referentes aos recursos materiais e equipamentos. Além desses, a falta de coordenação das atividades, o atendimento com descaso e a recusa do cirurgião em aceitar conduta proposta foram fatores encontrados em respectivamente $8,6 \%, 1,1 \%$ e $0,5 \%$ dos relatos analisados.

Desta maneira, verifica-se que os resultados do estudo de Silva(22) corroboram os achados de Wright, Mackenzie, Buchan, Cairns, Price(19) sendo que a maioria das ocorrências iatrogênicas, ou seja, 68,8\%, foram relacionadas aos fatores humanos contra $31,2 \%$ daquelas referentes aos equipamentos.

Desta forma, sendo o fator humano o mais relevante para o aparecimento de ocorrências iatrogênicas, ressalta-se a importância de uma capacitação adequada para os profissionais que estão envolvidos diretamente com a assistência, principalmente nos casos de atendimento à PCR. Safar(1); Muller, Borba (2); Lopez (4) e Vieira (23) citam que o atendimento adequado da PCR exige ação rápida e harmoniosa das várias pessoas nele envolvidas, enfatizando a necessidade de uma equipe bem treinada, não só nos aspectos relativos à participação isolada de cada um dos seus integrantes, mas também na ação em conjunto, a fim de que se possa atuar de forma efetiva, evitando a desorganização e a ineficiência do atendimento.

Frente aos problemas relacionados aos recursos materiais e de equipamentos, considerando-se a UTI como um sistema abrangente e complexo, dotada de infra-estrutura própria com recursos materiais, equipamentos adequados ao atendimento pronto e eficaz dos pacientes em estado grave, não se justifica a existência de problemas relacionados aos equipamentos durante o atendimento à PCR. Padilha (18) enfatiza a necessidade não só de suprimento adequado destes recursos, como também a manutenção periódica dos aparelhos, pois a insuficiência ou falha em seu funcionamento poderá acarretar perda de tempo para a equipe e consequente dano ao paciente, principalmente, nas situações de PCR.

A rotina de reposição e manutenção de materiais e equipamentos também deve conter os itens a serem checads no início de cada plantão e após cada atendimento tais como: verificar o perfeito 
funcionamento do ventilador mecânico, do desfibrilador, do aspirador, do laringoscópio, do ambu e demais equipamentos, pois sua finalidade só será atingida se estiverem em plenas condições de uso

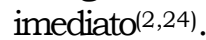

Nesse sentido, em pesquisa realizada pelo Departamento de Fiscalização do Conselho Regional de Medicina -SP (25) que vistoriou 49 UTIs, em 20\% do total existente no Estado de São Paulo foi constatado que embora as instituições públicas de saúde tivessem uma maior disponibilidade de recursos materiais e equipamentos, não procediam sua manutenção preventiva o que resultava em sucateamento precoce e impossibilidade de uso. O estudo ainda mostrou que a manutenção preventiva dos equipamentos existia em $57 \%$ das UTIs, prática no entanto predominante nos hospitais privados, sendo que nos públicos foi encontrada em apenas $43 \%$ dos serviços visitados. Referente ao atendimento à POR, constatou-se que um terço dos serviços não tinham o carrinho do atendimento de emergência completo. A proporção dos incompletos foi maior entre os hospitais públicos $(43 \%)$ do que entre os privados (29\%). Esses resultados demonstram a precariedade do funcionamento de boa parte das UTIs e a fragilidade do atendimento ao paciente nessas condições. Embora os problemas relacionados aos materiais e equipamentos possam ter como subjacente o fator humano, uma vez que dele depende o abastecimento do carrinho de emergência e a checagem de materiais e equipamentos, pode também estar relacionado ao suprimento, por problemas relacionados ao hospital como um todo. De qualquer forma, deixa também evidente falha na atuação da enfermagem, enquanto responsável pela manutenção dos recursos na unidade.

Ainda que a detecção e prevenção dos fatores iatrogênicos não dependam apenas dos recursos humanos existentes, acredita-se que a ênfase na capacitação dos vários profissionais que atuam no atendimento à PCR sejam fundamentais para uma melhor assistência. Esta capacitação deve começar já na formação acadêmica, num processo que exigirá treinamento e reciclagem contínuos, atualização de conhecimentos e desenvolvimento de habilidades técnicas conforme recomendadas pela American Heart Association (6), bem como simulações dos atendimentos em grupo, com a determinação de líderes que coordenem as ações e a utilização de protocolos que sumarizem as informações a serem seguidas durante o atendimento à PCR.

Kaye e Mancini(26) são enfáticas ao afirmar que os profissionais que não seguem as diretrizes propostas pela American Heart Association reforçam comportamentos incorrets nos events de POR. Assim sendo, acredita-se que as ocorrências iatrogênicas identificadas durante o atendimento à PCR na UTI possam ser desencadeadas não só pela ausência de um coordenador das atividades, como também pela inexistência de um protocolo de atendimento colocado de forma estratégica dentro da UTI.

\section{CONSIDERAÇÕES FINAIS}

O treinamento da equipe em relação ao atendimento da PCR na UTI deve ter como objetivo primordial reduzir ao mínimo a duração da mesma, com medidas que permitam atuação rápida, eficiente e sistematizada, atingindo automatização total, mas consciente, das diversas etapas do atendimento. Assim, não basta simplesmente uma orientação para que se considere o pessoal de UTI apto a exercer o conjunto de medidas de emergência para o tratamento da PCR. É necessário um contínuo treinamento e atualização dos conhecimentos e técnicas que permeiam toda a assistência nesse meio (24).

A presença de fatores iatrogênicos relacionados ao atendimento à PCR na UTI, parece demonstrar que o profissional que cuida de pacientes de maior complexidade necessita estar mais capacitado para atuar de forma segura e competente na vigência do atendimento, pois a falta de formação teórico-prática, freqüentemente, propicia o aparecimento de erros no decorrer da assistência e, conseqüentemente, insucesso de toda a ação.

Certamente, o investimento em treinamento para os profissionais que prestam assistência direta aos pacientes em PCR, a elaboração de protocolos para guiar a assistência a ser prestada na UTI podem proporcionar menor risco e, ter como resultado, maior segurança no decorrer do atendimento. Como já relatado, o fator humano é o mais frequentemente citado em se tratando de ocorrências iatrogênicas, porém os problemas relacionados aos equipamentos, ao processo de trabalho e a própria condição clinica do paciente não devem ser desconsiderados.

Visto sob este ângulo, faz-se necessário a implementação de medidas preventivas que enfoquem as ocorrências iatrogênicas no atendimento à PCR dentro de um contexto sistêmico, de forma a identificar e intervir nos pontos vulneráveis de qualquer um dos elementos constitutivos do cuidado, sejam os recursos humanos, recursos materiais e equipamentos, administrativos e técnicos. A atuação nesse sentido é que permitirá alcançar o propósito final da POR, voltado fundamentalmente para restaurar o processo de vida e não apenas prolongar o processo de morte do paciente. 


\section{REFERENCIAS BIBLIOGRÁFICAS}

(1) Safar P. Ressuscitação cardiorrespiratória cerebral. 2a ed. Rio de Janeiro: Interamericana; 1982.

(2) Muller AMA, Borba SRC. Papel do pessoal de enfermagem no atendimento à parada cardiaca no pequeno hospital. Rev Gaúcha Enferm 1986; 7(1):23-31.

(3) Barbisan JN. Reanimação cardiorrespiratória. Rev AMRIGS 1988; 32(2):122.

(4) Lopes M. Emergências médicas. $5^{\mathrm{a}}$ ed. Rio de Janeiro: Guanabara- Koogan; 1989.

(5) Lane JC. Organização em reanimação. In: Lane JC, Albarran-Sotelo R, editores. Reanimação cardiorrespiratória cerebral. Rio de Janeiro: Medsi; 1993. p.437-43. •

(6) American Heart Association. Suporte avançado de vida em cardiologia. Dallas; 1997

(7) Coelho OR. Ressuscitação cardiopulmonar. Rev Soc Cardiol Estado de São Paulo 1997; 7(1):1-7.

(8) Knobel E, Ferraz AC, Capone Neto A. Ressuscitação cerebral. Rev Soc Cardiol Estado de São Paulo 1997; 7(1):92-8.

(9) Azevedo AC. Avaliação de desempenho de serviços de saúde. Rev Saúde Públ 1991; 25(1):64-71.

(10) Azevedo AC. O futuro dos hospitais e a gestão da qualidade. Rev Paul Hosp 1992; 40(4):53.

(11) Padilha KG. Iatrogenias em unidade de terapia intensiva: uma abordagem teórica. Rev Paul Enferm 1992;11(2):6972 .

(12) Lynch ME. Iatrogenic hazards, adverse occurences and complications involving NICU nursing practice. J Perinat Neonatal Nurs $1991 ; 5(3): 78-86$.

(13) Beckmann U, Baldwin I, Hart GK, Runcimans WB. The Australian Incident Monitoring Study in Intensive Care: AIMS-ICU. The development and evaluation of na incident reporting system in intensive care. Anaesth Intensive Care 1996; 24(3):314-9.

(14) Short TG, Regan A, Lew J, Oh TE. Critical incident reporting in anaesthetic department quality assurance programme. Anaesthesia 1993; 48(1):3-7.

(15) Hart GK, Baldwuin I, Gutteridge G, Ford J. Adverse incident reporting in intensive care. Anaesth Intensive care 1994; 22(5): 556-61-

(16) Buckley TA, Short TG, Rowbottom YM, Oh TE. Critical incident reporting in the Intensive Care Unit. Anaesthesia 1997; 52(7):403-9.

(17) Padilha KG. Descuidar: as representações sociais dos enfermeiros de UTI sobre as ocorrências iatrogênicas de enfermagem [tese] São Paulo (SP): Escola de Enfermagem da USP; 1994.
(18) Padilha KG. Ocorrências iatrogênicas na prática de enfermagem em UTI [livre docência] São Paulo (SP):Escola de Enfermagem da USP; 1998.

(19)Wright D, Mackenzies S, Buchan I, Cairns CS, Price LE. Critical incidents in the intensive therapy unit. Lancet $1991 ; 338(8768): 676-8$.

(20) Whitaker IY. A enfermagem no atendimento de emergência In: Fellipe Junior $\boldsymbol{J}$, editor. Pronto socorro: diagnóstico e tratamento. $2^{a}$ ed. Rio de Janeiro: Guanabara-Koogan; 1990. p.119-25.

(21) Gray WA, Capone RJ, Most AS. Unsuccessful emergency medical resuscitation-are continued efforts in the emergency department justified ? N Engl J Med 1991; 325(20):1393-8.

(22) Silva SC. Parada cardiorrespiratória na unidade de terapia intensiva: análise das ocorrências iatrogênicas durante o atendimento. [dissertação] São Paulo (SP): Escola de Enfermagem da USP; 1998.

(23) Vieira RHG. Parada cardiorrespiratória em adulto hospitalizado: aspectos práticos para tomada de decisão. Texto Contexto Enf 1993; 2(2):99-110.

(24) Gomes AM. Enfermagem na unidade de terapia intensiva. $2^{*}$ ed. São Paulo: Pedagógica e Universitária;1998.

(25) Conselho Regional de Medicina-SP revela a insuficiência e precariedade que comprometem a qualidade do trabalho. Jornal do Cremesp 1998; 27:128-8.

(26) Kaye W, Mancini ME. Use of the mega code to evaluate team leader performance during advanced cardiac life support. Crit Care Med 1986;14(2):99-104.
Artigo recebido em 29/03/01

Artigo aprovado em 02/04/02 